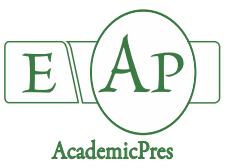

Erika V et al. (2020)

Notulae Botanicae Horti Agrobotanici Cluj-Napoca 48(2):735-751

DOI: $10.15835 /$ nbha48211851

Research Article

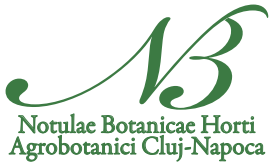

\title{
Biochar and Trichoderma aureoviride applied to the sandy soil: effect on soil quality and watermelon growth
}

\author{
Erika V. MEDEIROS ${ }^{1 *}$, Marcele C.H.S. MORAES ${ }^{1}$, Diogo P. COSTA ${ }^{1}$, \\ Gustavo P. DUDA ${ }^{1}$, Jenifer S.A. SILVA ${ }^{1}$, Julyana B. OLIVEIRA ${ }^{1}$, \\ José R.S. LIMA ${ }^{1}$, Romulo S.C. MENEZES ${ }^{2}$, Claude HAMMECKER ${ }^{3}$ \\ ${ }^{1}$ Universidade Federal do Agreste de Pernambuco, Garanbuns, Pernambuco, Brazil; evmbio@gmail.com ("corresponding author); \\ marcele-moraes@hotmail.com;diogocosta1@yahoo.com.br; gpduda@gmail.com;jenifersthephanie12@hotmail.com; \\ jully_bragaa@live.com;romualdo_solo@yahoo.com.br \\ ${ }^{2}$ Universidade Federal de Pernambuco, 1235 - Cidade Universitária, 50i70-901, Recife, Pernambuco, Brazil; rmenezes@ufpe.br \\ ${ }^{3}$ Institut de Recherche pour le Développement (IRD), 2, Place Pierre Viala, Montpellier, France; claude.hammecker@gmail.com
}

\section{Abstract}

Trichoderma spp. are an alternative to increase plant growth and as biological control agents of diseases. Biochar added to soil and Trichoderma can result in the enhancement of crop development and can aid in preventing fertilizer run-off, improving plant health, retaining soil moisture, and helping plants through drought periods. However, a knowledge gap remains regarding the combined effect of biochar and Trichoderma on soil quality and crop growth. The objective of the present study was to evaluate this combined effect and show a new approach of biochar as a route of $T$. aureoviride $(\mathrm{T})$ inoculation. We evaluated three sources of biochar, bean husks, coffee grounds, and coffee husks, with or without $\mathrm{T}$ and an additional control that was devoid of biochar and $\mathrm{T}$. The association of all biochar sources with $\mathrm{T}$ showed a significant increase in watermelon growth and soil quality. Biochar coffee grounds with $\mathrm{T}$ increased urease, $\beta$-glucosidase, and total organic carbon, showing the potential of this combination in these processes. Watermelon plants cultivated in soil with coffee ground biochar and T showed plant length and shoot dry biomass increases of 129\% and 192\%, respectively. Thus, this study found that biochar use plays an important role in the effectiveness of $T$. aureoviride applications and is a new instrument for sustainable agriculture.

Keywords: Citrullus lanatus; cycling of nutrients; microbial biomass; soil fertility; soil metabolism; vegetative growth

\section{Introduction}

Biochar is a stable product obtained from the pyrolysis of organic materials, such as rice straw, wood, manure, and leaves under a low oxygen $\left(\mathrm{O}_{2}\right)$ concentration. Originally, it was found in Amazonian regions in soil bands known as "Black Indian lands" (Saxena et al., 2013). During the last several years, this material has received prominence because of its potential for carbon sequestration, heavy metals adsorption, and increased 
availability of phosphorus $(\mathrm{P})$ in the soil because of the increase in $\mathrm{pH}$ and the adsorption of this nutrient on its surface (Elzobair et al., 2016; Yang et al., 2017). Biochar also increases cation exchange capacity, enzymatic activities, and water retention in soil, mitigating saline stress and improving the development of plants and microorganisms (Patel et al., 2017).

Among the microorganisms, we highlight the beneficial fungi of the genus Trichoderma, which act as agents for the biological control of phytopathogens and promote plant growth (Silva et al., 2016). Among the mechanisms conferred by these fungi is the increase in the area of root absorption because of the Trichoderma root association, resulting in a higher nutritional absorption, followed by an increase in the pathogen resistance factor (Oskiera et al., 2017). This fungus assists in conserving soils, increasing seed germination rates, mitigating abiotic interference effects, and characterizing a systemic defence accompanied by increases in soil productivity (Mendoza-Mendoza et al., 2018). The fungus T. aureoviride showed physiological and functional versatilities mentioned in previous studies, such as the capacity to produce the enzyme chitinase that acts on the cell wall of several fungi and in the direct biological control of phytopathogens. (Silva et al., 2016).

Considering the ease of cultural adaptation and economic relevance, the watermelon (Citrullus lanatus Thumb. Mansf.) culture constitutes a relevant model to evaluate the effects of biochar inoculated with Trichoderma because it has a short cycle, facilitating experimental trials, and its pulp, bark, and seeds are rich in minerals, vitamins, and proteins (Poduria et al., 2013).

There are several studies relating the beneficial effects of biochar applied to soil (Patel et al., 2017; Lima et al., 2018) and the use of Trichoderma as instrument to promote plant growth or biological control (Silva et al., 2017). Nonetheless, there is still a gap in knowledge regarding the effect of the combined application of both on soil quality and plant growth. There is no report regarding the use of this combined application of biochar and Trichoderma in watermelon culture; thus, this is a pioneering study in this context. This study presents the hypothesis that biochar is a potential vehicle for inoculation of Trichoderma spp., improving several soil attributes that in turn increase crop development. Therefore, the objective of the present study was to evaluate the combined effect of biochar and $T$. aureoviride on the improvement of soil quality and the initial development of watermelon plants.

\section{Materials and Methods}

\section{Trichoderma aureoviride strain and biochar application}

Biochar was obtained from industrial bean and coffee residues, namely, bean husks $(\mathrm{BH})$, coffee grounds (CG), and coffee husks $(\mathrm{CH})$. They were charred for 10 to $12 \mathrm{~h}$ under oxygen-limited conditions during a slow pyrolysis process where the temperature reached $530^{\circ} \mathrm{C}$ in a metallic kiln and were then sieved using a $2 \mathrm{~mm}$ sieve. The quality of the biochar has been assessed by Lima et al. (2018).

T. aureoviride URM 5158 isolate was obtained from the Micoteca URM collection of the Mycology Department of the Biological Sciences Center of the Federal University of Pernambuco (https://www.ufpe.br/micoteca/). The fungus conidia reactivated through three successive subcultures in an Erlenmeyer flask containing $50 \mathrm{ml}$ of potato dextrose agar liquid medium, grown at $26^{\circ} \mathrm{C} \pm 2{ }^{\circ} \mathrm{C}$ for eight days. Each treatment with $T$. aureoviride was sprayed with $100 \mathrm{ml}\left(1 \times 10^{6}\right.$ conidia per $\left.\mathrm{ml}\right)$ applied to each biochar source. The biochar and $T$. aureoviride were mixed with the soil before planting.

\section{Experimental setup}

A pot experiment was conducted in a greenhouse in Pernambuco, Brazil. The soil used for the experiment was a topsoil (the $0-20 \mathrm{~cm}$ layer) collected in a patch of native forest in São João $\left(08^{\circ} 48^{\prime} 34.2^{\prime \prime} \mathrm{S}\right.$, 
$36^{\circ} 24^{\prime} 29.3^{\prime \prime} \mathrm{W}$ ) at an elevation of $705 \mathrm{~m}$ above the mean sea level. The soil is a typical entisol with nearly 90 $\%$ sand and less than $5 \%$ clay with extremely low values of cation exchange capacity.

The chemical attributes of the soil and biochar before the experiment are shown in Lima et al. (2018). This soil was previously treated with a formulated fertilizer NPK (6:24:12) to prevent variations related to plant nutritional deficits. We added biochar corresponding to the application of $32 \mathrm{t} \mathrm{ha}^{-1}$ for each biochar, considering its incorporation in the first $20 \mathrm{~cm}$ of the soil.

The experimental design used was completely randomized in a double factorial scheme with an additional treatment $(3 \times 2+1)$, with four repetitions. The first factor represented three sources of biochar, $\mathrm{BH}, \mathrm{CG}$, and $\mathrm{CH}$, and the second considered inoculation $(\mathrm{T}+)$ and absence $(\mathrm{T}-)$ of $T$. aureoviride on these substrates. The additional treatment represented the absolute control without biochar or $T$. aureoviride.

We used a commercial variety of watermelon (variety 'Vereda style') used by the farmers in the region where the experiment was conducted. The seeds were previously treated with fungicide, and three seeds were sown per pot. Five days after emergence, thinning was performed to leave one plant per pot. The plants were irrigated daily with distilled water to maintain the soil at field capacity.

At the end of the experiment, 45 days after planting, the plants were removed to measure the diameter of the base (DIA), main branch length (LEN), shoot (SFB) and root fresh biomass (RFB), followed by their respective dry biomass after drying in a forced ventilation oven at $65^{\circ} \mathrm{C}$ until reaching the consistency of the dehydrated biomasses (shoot dry biomass, $\mathrm{SDB}$, and root dry biomass, $\mathrm{RDB}$ ). The experiments were repeated two times and the means of both were showed.

After removal of the plants from the pots, soils were collected for the determination of $\mathrm{pH}$ values in water $(1: 2.5)$ and the content of $\mathrm{P}, \mathrm{Na}^{+}, \mathrm{K}^{+}, \mathrm{Ca}^{2+}, \mathrm{Mg}^{2+}, \mathrm{Al}^{3+}$, and $\mathrm{H}+\mathrm{Al}^{3+}$, according to the methodology of Silva (2009). The inorganic labile $\mathrm{P}, \mathrm{Na}^{+}$, and $\mathrm{K}^{+}$were extracted using Mehlich's solution $1\left(\mathrm{H}_{2} \mathrm{SO}_{4} 0.125 \mathrm{~mol}\right.$ $\left.\mathrm{L}^{-1}+\mathrm{HCl} 0.5 \mathrm{~mol} \mathrm{~L}^{-1}\right)$. The $\mathrm{P}$ was quantified using spectrophotometric colorimetry and the $\mathrm{Na}^{+}$and $\mathrm{K}^{+}$were determined using flame photometry. The $\mathrm{Ca}^{2+}, \mathrm{Mg}^{2+}$, and $\mathrm{Al}^{3+}$ were extracted with a $\mathrm{KCl} 1.0 \mathrm{~mol} \mathrm{~L}^{-1}$ solution; the first two were determined using atomic absorption spectrometry (Raij et al., 2001). Potential acidity $\left(\mathrm{H}+\mathrm{Al}^{3+}\right)$ was determined using calcium acetate $\left(\mathrm{Ca}\left(\mathrm{CH}_{3} \mathrm{OO}\right)_{2} \mathrm{H}_{2} \mathrm{O}\right)$ at $\mathrm{pH}$ 7.0. In addition, $\mathrm{Al}^{3+}$ was determined via titration with $\mathrm{NaOH} 0.025 \mathrm{~mol} \mathrm{~L}^{-1}$ using bromothymol blue as an indicator. In all extractions, $5.0 \mathrm{~g}$ of soil was used for $50 \mathrm{~mL}$ of extractive solution $(1: 10)$.

Total organic carbon content (TOC) was obtained using the $\mathrm{C}$ oxidation method in a wet form with potassium dichromate followed by determination of remaining $\mathrm{Cr}_{2} \mathrm{O}_{7}{ }^{2-}$ via titration with ammonium iron (II) sulfate (Yeomans and Bremner, 1988). The microbial biomass carbon (MBC) was determined using the methodology of irradiation (Mendonça, 2005) with the extraction carried out by the addition of $80 \mathrm{~mL}$ of $\mathrm{K}_{2} \mathrm{SO}_{4} 0.5 \mathrm{M}$ to each $20 \mathrm{~g}$ of soil (Tate et al., 1988). The $\mathrm{C}$ content was determined using colorimetry (Bartlett and Ross, 1988).

The evolution of $\mathrm{CO}_{2}$ released by microbial respiration was also measured for the calculation of soil basal respiration and the soil metabolic quotient $\left(q \mathrm{CO}_{2}\right)$ using the alkaline adsorption method. For this purpose, at the end of the experiment, the soil was maintained at $60 \%$ of field capacity based on gravimetry (Anderson and Domsch, 1985). Then, $30 \mathrm{~g}$ of each sample were hermetically sealed in containers to capture $\mathrm{CO}_{2}$ with $10 \mathrm{~mL}$ of $\mathrm{NaOH} 0.5 \mathrm{M}$ solution. After $72 \mathrm{~h}, 2 \mathrm{~mL}$ of $\mathrm{BaCl} 10 \%(\mathrm{~m} / \mathrm{v})$ solution were added for total precipitation of $\mathrm{CO}_{2}$, followed by two drops of phenolphthalein diluted in $100 \mathrm{ml}$ of ethyl alcohol $95 \%$ ( $\mathrm{v} / \mathrm{v}$ the determinations being carried out by titration with $\mathrm{HCl} 0.25 \mathrm{M}$ ).

Enzymatic soil activities were determined by estimating the gene expression of the main processes related to acidic (P. Aci) and alkaline phosphatases (P. Alk) (E.C. 3.1.3), $\beta$-glucosidase (Beta) (E.C. 3.2.1.21), and urease (Ure) (E.C. 3.5.1.5) according to the colorimetric analysis of the products released by the samples subjected to incubation in an adequate substrate (Sigma-Aldrich). The activities of P. Aci and P. Alk were estimated according to the methodology of Eivazi and Tabatabai (1977). Beta was estimated using the methodology of Eivazi and Tabatabai (1988), and Ure was estimated using the method by Kandeler and Gerber (1988). Product absorbance was measured using a spectrophotometer (Libra S22, Biochrom, Cambridge, UK). 


\section{Statistical analyses}

Statistical and multivariate analyses were conducted using the R language platform (v.3.4.3, 2017) based on the data of the biometric attributes of the plants, chemicals, and enzymatic activities of the soils. Multivariate exploratory analyses including nonmetric multidimensional scaling (nMDS), analysis of similarity (ANOSIM), heatmaps, and Mantel tests were completed based on the tools of the vegan and heatmaply libraries. After adjusting the models and removing the outliers, the means, standard deviations, and variation coefficients were calculated using the doBy library. Homogeneity tests, analysis of variances (ANOVA), and comparisons between averages were completed with the balanced data, according to the tools contained in the stats, AxpDes, multicomp, and agricolae libraries. Residues from all datasets were considered normal, with the exception of SDB and K, which were adequately transformed for ANOVA.

\section{Results}

The results showed the influence of the biochar source types and T. aureoviride on watermelon plant attributes (Table 1), soil chemical attributes (Table 2 ) and metabolic pattern of the soil microbial community (Table 3).

Table 1. Watermelon plants attributes (cv. Vereda style) treated with biochar from coffee grounds (CG), coffee husks $(\mathrm{CH})$, and bean husks $(\mathrm{BH})$, with $(+T)$ and without $(-T)$ inoculation of Trichoderma

\begin{tabular}{|c|c|c|c|c|c|c|}
\hline \multirow[b]{3}{*}{$+\mathrm{T}$} & \multirow{2}{*}{\multicolumn{2}{|c|}{$\frac{\mathrm{CG}}{\text { 1. Length }(\mathrm{cm})}$}} & \multicolumn{2}{|c|}{$\mathrm{CH}$} & \multicolumn{2}{|c|}{$\mathrm{BH}$} \\
\hline & & & & & & \\
\hline & 95.6 & $\mathrm{aA}$ & 79.3 & $\mathrm{~b}$ & $\underline{91.7}$ & $\mathrm{a}$ \\
\hline \multirow[t]{3}{*}{$-\mathrm{T}$} & 69.3 & bB & 75 & $\mathrm{~b}$ & 91.3 & $\mathrm{a}$ \\
\hline & $C=73.56$ & & & & & \\
\hline & \multicolumn{2}{|c|}{ 2. Diameter $(\mathrm{cm})$} & & & & \\
\hline$+\mathrm{T}$ & 7.2 & $\mathrm{aA}$ & 6.4 & bB & 7.4 & aA \\
\hline \multirow[t]{3}{*}{$-\mathrm{T}$} & 6.7 & $\mathrm{abB}$ & 7.1 & aA & 6.6 & bB \\
\hline & $C=6.78$ & & & & & \\
\hline & \multicolumn{2}{|c|}{ 3. $S F M(g)$} & & & & \\
\hline$+\mathrm{T}$ & 76.7 & $\mathrm{aA}$ & $\underline{60}$ & $\mathrm{bA}$ & $\underline{73.3}$ & $\mathrm{a}$ \\
\hline \multirow[t]{3}{*}{$-\mathrm{T}$} & $\underline{60.6}$ & bB & 47.8 & $\mathrm{cB}$ & $\underline{75}$ & $\mathrm{a}$ \\
\hline & $\mathrm{C}=44.78$ & & & & & \\
\hline & \multicolumn{2}{|c|}{ 4. $R F M(g)$} & & & & \\
\hline$+\mathrm{T}$ & $\underline{4.2}$ & $\mathrm{bA}$ & 2.5 & $\mathrm{cA}$ & 6.1 & $\mathrm{aA}$ \\
\hline \multirow[t]{3}{*}{$-\mathrm{T}$} & $\overline{2.3}$ & bB & 0.7 & $\mathrm{cB}$ & $\overline{\underline{4}}$ & $\mathrm{aB}$ \\
\hline & $C=2.36$ & & & & & \\
\hline & \multicolumn{2}{|c|}{ 5. $S D M(g)$} & & & & \\
\hline$+\mathrm{T}$ & $\underline{28.9}$ & aA & 15.6 & $\mathrm{bA}$ & $\underline{28.3}$ & a \\
\hline \multirow[t]{3}{*}{$-\mathrm{T}$} & $\overline{14.4}$ & $\mathrm{bB}$ & 9.4 & bB & 25.8 & $\mathrm{a}$ \\
\hline & $\mathrm{C}=15.00$ & & & & & \\
\hline & \multicolumn{2}{|c|}{ 6. $R D M(g)$} & & & & \\
\hline$+\mathrm{T}$ & $\underline{0.21}$ & $\mathrm{~b}$ & $\underline{0.14}$ & $\mathrm{cA}$ & $\underline{0.44}$ & aA \\
\hline \multirow[t]{2}{*}{$-\mathrm{T}$} & $\underline{0.17}$ & $\mathrm{~b}$ & 0.06 & $c B$ & $\underline{0.32}$ & $\mathrm{aB}$ \\
\hline & $\mathrm{C}=0.047$ & & & & & \\
\hline
\end{tabular}

LEN= plant length; DIA = diameter; $\mathrm{SFM}=$ shoot fresh mass; RFM= root fresh mass; $\mathrm{SDM}=$ shoot dry mass; RDM= root dry mass. Means followed by the same lowercase in the line (between different sources of biochar) and upper case in the column (between the effects of Trichoderma aureoviride), do not differ statistically by Tukey's test at 5\%. The absence of letters indicates that the means are statistically equal to the $5 \%$ level using the $\mathrm{F}$ test. The underlined averages differ significantly from the respective control treatments (C) by Dunnett test at $5 \%$ 
The inoculation of $T$. aureoviride with biochar also demonstrated a significant increase that was, higher than that in the control treatment, with the exception of the diameter. However, the results demonstrated a significant positive effect of $T$. aureoviride inoculation on the vegetative development of watermelon plants grown in a regolithic neosol treated using different biochar sources.

Table 2. Chemical attributes of soil cultivated with watermelon (cv. Vereda style) treated with biochar from coffee grounds $(\mathrm{CG})$, coffee husks $(\mathrm{CH})$, and bean husks $(\mathrm{BH})$, with $(+T)$ and without $(-T)$ inoculation of Trichoderma aureoviride

\begin{tabular}{|c|c|c|c|c|c|c|}
\hline & \multirow{2}{*}{\multicolumn{2}{|c|}{$\frac{\mathrm{CG}}{1 . p H}$}} & \multicolumn{2}{|c|}{$\mathrm{CH}$} & \multicolumn{2}{|c|}{$\mathrm{BH}$} \\
\hline & & & & & & \\
\hline$+\mathrm{T}$ & 5.57 & $\mathrm{~b}$ & $\underline{7}$ & $\mathrm{aB}$ & $\underline{6.74}$ & $\mathrm{a}$ \\
\hline \multirow[t]{3}{*}{$-\mathrm{T}$} & $\underline{5.48}$ & c & $\underline{7.89}$ & aA & $\underline{6.65}$ & $\mathrm{~b}$ \\
\hline & \multicolumn{3}{|c|}{$C=4.54$} & & & \\
\hline & \multicolumn{4}{|c|}{ 2. $\mathrm{Na}^{2+}\left(\mathrm{cmolc} \mathrm{kg}^{-1}\right)$} & & \\
\hline$+\mathrm{T}$ & 0.82 & $\mathrm{ab}$ & 0.93 & $\mathrm{a}$ & 0.82 & $\mathrm{~b}$ \\
\hline \multirow[t]{3}{*}{$-\mathrm{T}$} & 0.89 & $\mathrm{ab}$ & 0.89 & $\mathrm{a}$ & 0.85 & $\mathrm{~b}$ \\
\hline & \multicolumn{3}{|c|}{$\mathrm{C}=0.821$} & & & \\
\hline & \multicolumn{4}{|c|}{ 3. $K^{+}\left(\right.$cmolc $\left.g^{-1}\right)$} & & \\
\hline$+\mathrm{T}$ & $\underline{2.13}$ & $\mathrm{c}$ & $\underline{6.7}$ & $\mathrm{a}$ & $\underline{3.97}$ & bB \\
\hline \multirow[t]{3}{*}{$-\mathrm{T}$} & 2.13 & $\mathrm{~b}$ & $\underline{5.93}$ & $\mathrm{a}$ & $\underline{5.19}$ & $\mathrm{aA}$ \\
\hline & \multicolumn{3}{|c|}{$C=0.596$} & & & \\
\hline & \multicolumn{3}{|c|}{ 4. $P\left(m g k g^{-1}\right)$} & & & \\
\hline$+\mathrm{T}$ & $\underline{2.03}$ & c & $\underline{3.02}$ & $\mathrm{~b}$ & $\underline{4.14}$ & aA \\
\hline \multirow[t]{3}{*}{$-\mathrm{T}$} & $\underline{2.3}$ & $\mathrm{~b}$ & $\underline{\underline{3.03}}$ & $\mathrm{a}$ & $\underline{3.4}$ & $\overline{\mathrm{aB}}$ \\
\hline & \multicolumn{3}{|c|}{$C=0.875$} & & & \\
\hline & \multicolumn{5}{|c|}{ 5. $H^{+}+A l^{3+}\left(\right.$ cmol $\left._{c} d m^{-3}\right)$} & \\
\hline$+\mathrm{T}$ & $\underline{1.13}$ & $\mathrm{aB}$ & $\underline{0.52}$ & $\mathrm{~b}$ & $\underline{0.63}$ & $\mathrm{~b}$ \\
\hline \multirow[t]{3}{*}{$-\mathrm{T}$} & $\underline{1.4}$ & aA & $\underline{0.47}$ & $\mathrm{~b}$ & $\underline{0.52}$ & $\mathrm{~b}$ \\
\hline & \multicolumn{3}{|c|}{$C=1.84$} & & & \\
\hline & \multicolumn{5}{|c|}{ 6. $\mathrm{Ca}^{2+}\left(\mathrm{cmol}_{c} \mathrm{dm}^{-3}\right)$} & \\
\hline$+\mathrm{T}$ & 0.39 & $\mathrm{aB}$ & $\underline{0.45}$ & $\mathrm{a}$ & $\underline{0.44}$ & aA \\
\hline \multirow[t]{3}{*}{$-\mathrm{T}$} & $\underline{0.46}$ & aA & $\underline{0.42}$ & $\mathrm{ab}$ & 0.39 & $\mathrm{bB}$ \\
\hline & \multicolumn{3}{|c|}{$C=0.346$} & & & \\
\hline & \multicolumn{5}{|c|}{ 7. $M g^{2+}\left(\mathrm{cmol}_{c} d m^{-3}\right)$} & \\
\hline$+\mathrm{T}$ & 0.36 & $\mathrm{~b}$ & $\underline{0.38}$ & $\mathrm{~b}$ & $\underline{0.6}$ & $\mathrm{a}$ \\
\hline \multirow[t]{2}{*}{$-\mathrm{T}$} & $\underline{0.4}$ & $\mathrm{~b}$ & $\underline{0.4}$ & $\mathrm{~b}$ & $\underline{0.57}$ & $\mathrm{a}$ \\
\hline & \multicolumn{3}{|c|}{$C=0.250$} & & & \\
\hline
\end{tabular}

Means followed by the same lowercase in the line (between different sources of biochar) and upper case in the column (between the effects of Trichoderma aureoviride), do not differ statistically by Tukey's test at 5\%. The absence of letters indicates that the means are statistically equal to the $5 \%$ level using the $\mathrm{F}$ test. The underlined averages differ significantly from the respective control treatments (C) by Dunnett test at $5 \%$. 
Table 3. Enzyme activities, total organic carbon, microbial biomass carbon and methabolic quotient of soil cultivated with watermelon plants treated with biochar from coffee grounds (CG), coffee husks $(\mathrm{CH})$, and bean husks $(\mathrm{BH})$, with $(+T)$ and without $(-T)$ inoculation of Trichoderma aureoviride

\begin{tabular}{|c|c|c|c|c|c|c|}
\hline & \multicolumn{2}{|c|}{$\mathrm{CG}$} & \multicolumn{2}{|c|}{$\mathrm{CH}$} & \multicolumn{2}{|c|}{$\mathrm{BH}$} \\
\hline & \multicolumn{6}{|c|}{ 1. Ure $\left(\mu g N H_{4}-N g^{-1} d w t 2 b^{-1}\right)$} \\
\hline$+\mathrm{T}$ & 30.6 & $\mathrm{~b}$ & 44.4 & $\mathrm{a}$ & $\underline{40.4}$ & a \\
\hline \multirow[t]{3}{*}{$-\mathrm{T}$} & $\underline{31.3}$ & $\mathrm{~b}$ & $\underline{43.9}$ & a & $\underline{44.3}$ & a \\
\hline & \multicolumn{3}{|c|}{$C=25.32$} & & & \\
\hline & \multicolumn{6}{|c|}{ 2. Beta ( $\mu g p$-Nitrof. $g^{-1}$ soil $\left.h^{-1}\right)$} \\
\hline$+\mathrm{T}$ & $\underline{58.6}$ & aA & 43.4 & $\mathrm{bA}$ & 48.1 & bA \\
\hline \multirow[t]{3}{*}{$-\mathrm{T}$} & 53 & $\mathrm{aB}$ & 35.9 & $\mathrm{bB}$ & 40.3 & $\mathrm{bB}$ \\
\hline & \multicolumn{3}{|c|}{$C=39.75$} & & & \\
\hline & \multicolumn{6}{|c|}{ 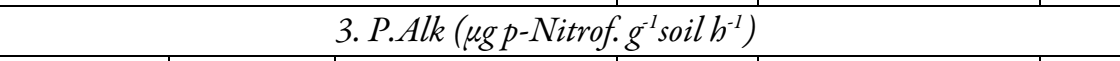 } \\
\hline$+\mathrm{T}$ & 3.1 & aA & 1.7 & $\mathrm{~b}$ & 2.4 & $\mathrm{ab}$ \\
\hline \multirow[t]{3}{*}{$-\mathrm{T}$} & 1.1 & bB & 2.5 & a & 2.6 & a \\
\hline & \multicolumn{3}{|c|}{$C=2.26$} & & & \\
\hline & \multicolumn{6}{|c|}{ 4.P.Aci $\left(\mu g\right.$ p-Nitrof. $g^{-1}$ soil $\left.h^{-1}\right)$} \\
\hline$+\mathrm{T}$ & 1.9 & a & 1.5 & $\mathrm{~b}$ & 2.3 & $\mathrm{ab}$ \\
\hline \multirow[t]{3}{*}{$-\mathrm{T}$} & 3.7 & a & 1.1 & $\mathrm{~b}$ & 2.4 & $\mathrm{ab}$ \\
\hline & \multicolumn{3}{|c|}{$C=1.40$} & & & \\
\hline & \multicolumn{5}{|c|}{ 5. TOC ( $\mathrm{g} \mathrm{kg}^{-1}$ soil $)$} & \\
\hline$+\mathrm{T}$ & $\underline{12.8}$ & a & 8.7 & $\mathrm{~b}$ & $\underline{10.5}$ & $\mathrm{~b}$ \\
\hline \multirow[t]{3}{*}{$-\mathrm{T}$} & $\underline{12.9}$ & a & $\underline{9.4}$ & $\mathrm{~b}$ & 8.7 & $\mathrm{~b}$ \\
\hline & \multicolumn{3}{|c|}{$C=6.88$} & & & \\
\hline & \multicolumn{5}{|c|}{ 6. $M B C$ ( $g \mathrm{~kg}^{-1}$ soil) } & \\
\hline$+\mathrm{T}$ & 0.1 & $\mathrm{~b}$ & 0.3 & $a b$ & 0.3 & $\mathrm{aB}$ \\
\hline \multirow[t]{3}{*}{$-\mathrm{T}$} & 0.2 & $\mathrm{~b}$ & 0.2 & $\mathrm{~b}$ & $\underline{0.5}$ & aA \\
\hline & \multicolumn{3}{|c|}{$C=0.16$} & & & \\
\hline & \multicolumn{6}{|c|}{ 7. $q \mathrm{CO}_{2}\left(m g C-\mathrm{CO}_{2} g^{-1} B M S-C h^{-1}\right)$} \\
\hline$+\mathrm{T}$ & 2.4 & $\mathrm{abA}$ & 2.5 & $\mathrm{aB}$ & 2 & $\mathrm{bA}$ \\
\hline \multirow[t]{2}{*}{$-\mathrm{T}$} & 1.5 & $\mathrm{abB}$ & 2.9 & aA & 0.7 & $\mathrm{bB}$ \\
\hline & \multicolumn{3}{|c|}{$\mathrm{C}=2.04$} & & & \\
\hline
\end{tabular}

Ure= soil Urease; Beta $=\beta$-glycosidase; P.alk= alkaline phosphatase; P.aci=acid phosphatase activities; $\mathrm{TOC}=$ total organic carbon; $\mathrm{MBC}=$ microbial biomass carbon; $\mathrm{qCO} 2=$ soil metabolic quotient. Means followed by the same lowercase in the line (between different sources of biochar) and upper case in the column (between the effects of Trichoderma aureoviride), do not differ statistically by Tukey's test at $5 \%$. The absence of letters indicates that the means are statistically equal to the $5 \%$ level using the $\mathrm{F}$ test. The underlined averages differ significantly from the respective control treatments (C) by Dunnett test at $5 \%$

The plant biometric variables significantly responded to both biochar type and $\mathrm{T}$ in contrast with the control treatment. Most of the plant parameters were strongly influenced (increased) by CG or BH and T application into the soil (Table 1). For example, the application of CG biochar with Trichoderma aureoviride to the soil increased the plant length, diameter, shoot fresh and dry matter and root dry matter $(1.3 ; 1.06 ; 1.7$; 
1.9; 4.4 times, respectively). Watermelon plants that received $\mathrm{BH}$ biochar with $\mathrm{T}$ also showed increases, mainly on DIA, RFM, and RDM (9.3 times compared to the control).

The addition of biochar, in general, increased the $\mathrm{pH}$ and the $\mathrm{P}, \mathrm{K}^{+}, \mathrm{Ca}^{2+}$, and $\mathrm{Mg}^{2+}$ and decreased the $\mathrm{H}+\mathrm{Al}^{3+}$ compared to the control. $\mathrm{BH}$ was also generally responsible for the higher levels of $\mathrm{P}$, particularly when applied with $T$. aureoviride (increase of 4.7 timescompared to the control), differing from all other treatments, with the exception of CG (T-) (Table 2). The treatments with CG and BH also contributed to a reduction in potential acidity $\left(\mathrm{H}+\mathrm{Al}^{3+}\right)$, which was higher than that of $\mathrm{CG}$, in general and was closely correlated with the changes in $\mathrm{pH}$. The $\mathrm{Ca}^{2+}$ responses to the treatments were quite varied and were the same as the treatments with CG (T-), CG (T+ and $\mathrm{T}-$ ), and $\mathrm{BH}(\mathrm{T}+)$, which were all superior to $\mathrm{CG}(\mathrm{T}+)$ and $\mathrm{BH}(\mathrm{T}-)$.

The chemical variables $\mathrm{pH}, \mathrm{Na}^{+}, \mathrm{K}^{+}, \mathrm{P}$, and $\mathrm{H}+\mathrm{Al}^{3+}$ significantly responded to the isolated effect of different biochar sources, while only the $\mathrm{pH}$ showed a significant response to the isolated effect of $\mathrm{T}$ inoculation (Table 2). However, $\mathrm{T}$ showed a significant interaction with biochar for the variables $\mathrm{pH}, \mathrm{P}, \mathrm{K}^{+}, \mathrm{Ca}^{2+}$, and $\mathrm{H}+\mathrm{Al}^{3+}$. The chemical attributes of the control differed from those of all the other treatments, the only exception being $\mathrm{Na}^{+}$content. The application of $\mathrm{BH}$ with T increased $\mathrm{P}$ (4.7 times), $\mathrm{Ca}^{2+}\left(1.2\right.$ times) and $\mathrm{Mg}^{2+}$ (2.4 times).

Biochar applied to the soil increased Ure, except in the treatment CG $(\mathrm{T}+)$. In addition, Ure activity in soils with $\mathrm{CH}$ and $\mathrm{BH}$ was higher than that of soils with $\mathrm{CG}$ and the opposite was observed in Beta, with its activity being significantly more expressed in CG soils (Table 3). This was the only substrate that provided a significant increase in this activity in relation to the control, regardless of the presence of $\mathrm{T}$. Beta activity was also the only variable among the metabolic attributes whose significantly increased because of the inoculation with $\mathrm{T}$ for all biochars, mainly the application of $\mathrm{CG}$ with $\mathrm{T}$ that increase 1.5 times the Beta activity, showing its relevant participation in the hydrolysis of carbon sources.

The activity of P. Alk showed significant responses in the interaction of biochar $x \mathrm{~T}$. In this manner, the treatments diversified the responses of this enzyme, emphasizing that, in soils with $\mathrm{CG}(\mathrm{T}+)$, there was higher expression of $\mathrm{P}$. Alk, significantly contrasting with CG (T-), with less activity (Table 3).

Soils that received CG showed superior TOC (almost 2 times) content in relation to the control treatments, $\mathrm{CH}$ and $\mathrm{BH}$, similar to Beta (Table 3). The soil MBC significantly varied with the interaction between biochar and $\mathrm{T}$ because of the highest accumulation of microbial carbon in the soils with $\mathrm{BH}(\mathrm{T}-)$, significantly contrasting $\mathrm{BH}(\mathrm{T}+)$ and the control. The metabolic quotient $\left(q \mathrm{CO}_{2}\right)$ also showed varied responses, highlighting its significantly higher expression in CG. The T inoculation on CG and $\mathrm{BH}$ significantly increased $q \mathrm{CO}_{2}$, though the inverse was observed in CG. Ordering nMDS had a low stress $\left(S_{m}=\right.$ 0.11 ), showing an explanation of the treatment effects (biochar and $\mathrm{T}$ ) on the metabolic and sensory activities of chemical vectors and biometric attributes (Figure 1). A control treatment was positioned in a quadrant opposite to the vectors related to the $\mathrm{P}$ and the main soil bases $\left(\mathrm{Mg}^{2+}, \mathrm{Ca}^{2+}\right.$, and $\left.\mathrm{K}^{+}\right)$, and to the growth attributes of plants, in which it showed that this treatment had the lowest values. These variables showed a higher association of $\mathrm{BH}$ with $\mathrm{MBC}$ and with Ure activity in the soil that pointed to a higher contribution of $\mathrm{BH}$ in nutrient accumulation and $\mathrm{N}$ cycling in the development of plants and soil microbial communities. 


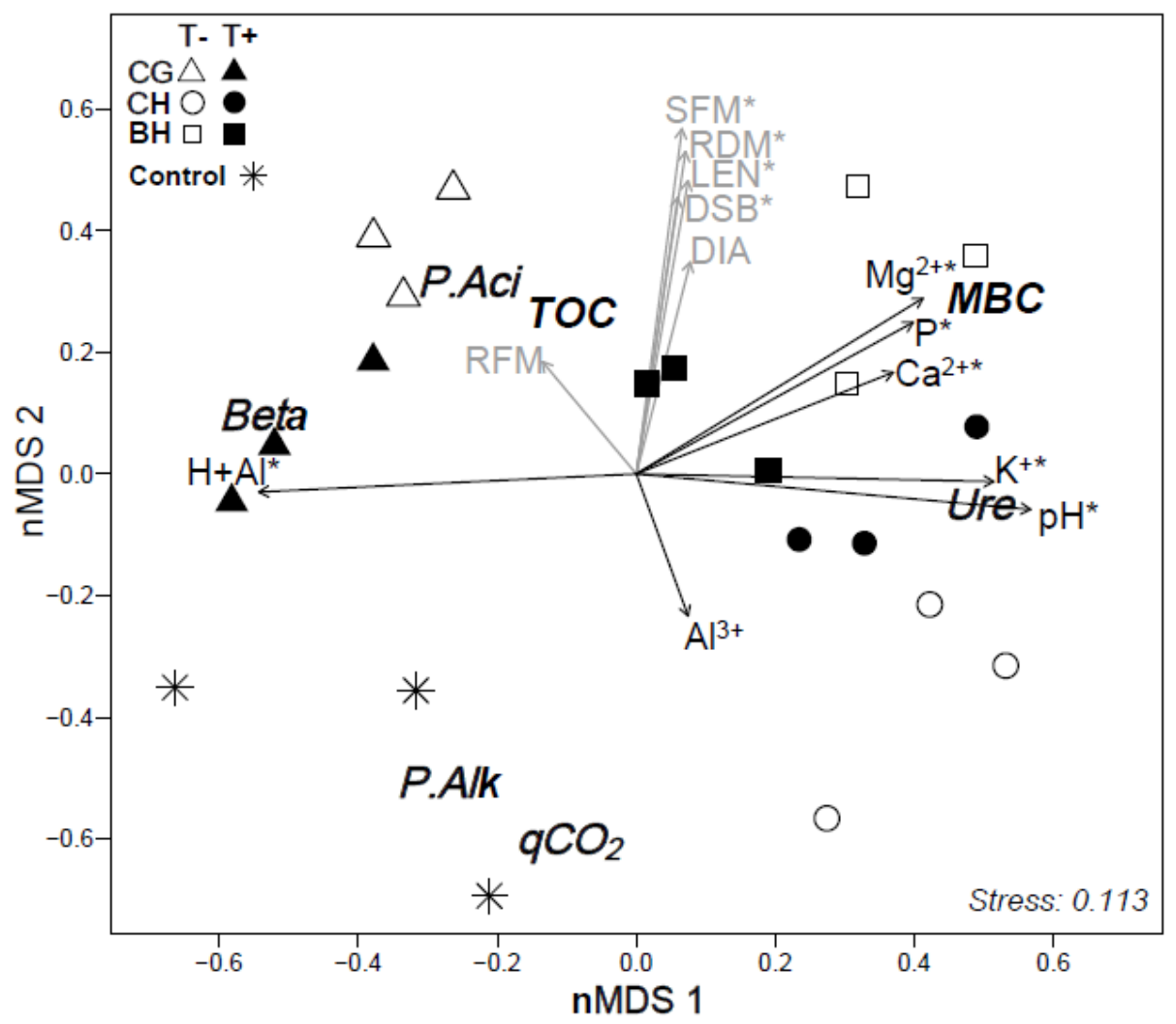

Figure 1. Dissimilarities between the metabolic activities of microorganisms in soils enriched with biochar from bean husks $(B H)$, coffee grounds $(C G)$, and coffee husks $(C H)$, with $(T+)$ and without $(T-) T$. aureoviride. Nonmetric multidimensional scaling (nMDS) showed a reasonable fit of the explanatory model, according to the stress measure $\left(S_{m}=.113, K_{\text {(dimension) }}=3\right)$ by Kruskal $(1964)$. The vectors corresponding to the chemical attributes (black) and biometrics (gray) followed by asterisks $\left(^{*}\right)$ have significant correlations $(\rho \leq 0.05)$

Urease (Ure), $\beta$-glycosidase (Beta), alkaline phosphatase (P.Alk), acid phosphatase (P.Aci), total organic carbon (TOC), microbial biomass carbon (MBC), soil metabolic quotient (qCO2); root dry matter (RDM) and root fresh matter (RFM), shoot dry mass (SDM), and shoot fresh matter (SFM), length (LEN) and diameter (DIA) of watermelon branches

Soils treated with CG biochar showed a higher RFB and levels of $\mathrm{H}+\mathrm{Al}^{3+}$, as these vectors are negatively correlated with soil $\mathrm{pH}$. Because the independent vectors $\mathrm{RFB}$ and $\mathrm{Al}^{3+}$ were opposed to each other, the negative effect of the increased $\mathrm{Al}^{3+}$ exchangeable on the root development was reiterated, showing that the approximation between $\mathrm{RFB}$ and $\mathrm{H}+\mathrm{Al}^{3+}$ is more related to the $\mathrm{H}^{+}$concentrations in the soil and not to $\mathrm{Al}^{3+}$, as expected. In addition, soils with CG showed the highest responses for P. Aci, Beta, and TOC. In general, the metabolic activities of the soils with CG distanced themselves from the soils with $\mathrm{CH}$ and $\mathrm{BH}$; these dissimilarities are primarily explained by the differences that these sources exert in soil chemical attributes.

The ANOSIM test confirmed the occurrence of strong segregations among the biometric and chemical attributes (Table 4). In general, all the attributes observed in the control distanced themselves without overlapping their correspondents in the other treatments $\left(R_{\text {Anosim }}>.75\right)$, with the exception of the biometric attributes of plants grown on soils with $\mathrm{CH}(\mathrm{T}-)$, although they have still distanced themselves $\left(R_{\text {Anosim }}=.56\right.$, Table 4). 
Table 4. Analysis of similarity of attributes from coffee grounds (CG), coffee husks (CH), and bean husks $(\mathrm{BH})$ with $(+\mathrm{T})$ and without $(-\mathrm{T})$ inoculation of Trichoderma aureoviride, under cultivation of watermelon plants of the variety Vereda style

\begin{tabular}{|c|c|c|c|c|c|c|}
\hline & $\mathrm{CH}(\mathrm{T}+)$ & $\mathrm{CG}(\mathrm{T}+)$ & $\mathrm{BH}(\mathrm{T}+)$ & $\mathrm{CH}(\mathrm{T}-)$ & $\mathrm{CG}(\mathrm{T}-)$ & $\mathrm{BH}(\mathrm{T}-)$ \\
\hline \multicolumn{7}{|c|}{ a. Metabolic attribute $(R-G l o b a l=0.86 ; p<0.0001)$} \\
\hline Control & $\underline{1.00}$ & $\underline{0.93}$ & $\underline{1.00}$ & $\underline{1.00}$ & $\underline{1.00}$ & $\underline{1.00}$ \\
\hline $\mathrm{CH}(\mathrm{T}+)$ & & $\underline{1.00}$ & 0.70 & 0.56 & $\underline{1.00}$ & 0.41 \\
\hline $\mathrm{CG}(\mathrm{T}+)$ & & & $\underline{1.00}$ & $\underline{1.00}$ & 0.56 & $\underline{1.00}$ \\
\hline $\mathrm{BH}(\mathrm{T}+)$ & & & & $\underline{0.96}$ & $\underline{1.00}$ & 0.67 \\
\hline $\mathrm{CH}(\mathrm{T}-)$ & & & & & $\underline{1.00}$ & $\underline{0.96}$ \\
\hline $\mathrm{CG}(\mathrm{T}-)$ & & & & & & $\underline{1.00}$ \\
\hline \multicolumn{7}{|c|}{ b. Biometric attribute $(R-G l o b a l=0.58 ; p<0.0001)$} \\
\hline Control & $\underline{1.00}$ & $\underline{1.00}$ & $\underline{1.00}$ & 0.56 & $\underline{1.00}$ & $\underline{1.00}$ \\
\hline $\mathrm{CH}(\mathrm{T}+)$ & & $\underline{0.96}$ & $\underline{0.93}$ & 0.56 & 0.22 & $\underline{0.93}$ \\
\hline $\mathrm{CG}(\mathrm{T}+)$ & & & 0.30 & 0.56 & $\underline{1.00}$ & -0.30 \\
\hline $\mathrm{BH}(\mathrm{T}+)$ & & & & 0.56 & $\underline{0.89}$ & 0.19 \\
\hline $\mathrm{CH}(\mathrm{T}-)$ & & & & & 0.56 & 0.56 \\
\hline $\mathrm{CG}(\mathrm{T}-)$ & & & & & & $\underline{1.00}$ \\
\hline \multicolumn{7}{|c|}{ c. Chemical attribute $(R-$ Global $=0.59 ; p<0.0001)$} \\
\hline Control & $\underline{1.00}$ & $\underline{0.89}$ & $\underline{1.00}$ & $\underline{1.00}$ & $\underline{1.00}$ & $\underline{1.00}$ \\
\hline $\mathrm{CH}(\mathrm{T}+)$ & & $\underline{1.00}$ & 0.44 & 0.56 & $\underline{1.00}$ & 0.41 \\
\hline $\mathrm{CG}(\mathrm{T}+)$ & & & 0.37 & $\underline{1.00}$ & -0.22 & $\underline{1.00}$ \\
\hline $\mathrm{BH}(\mathrm{T}+)$ & & & & 0.37 & 0.26 & -0.04 \\
\hline $\mathrm{CH}(\mathrm{T}-)$ & & & & & $\underline{1.00}$ & 0.30 \\
\hline $\mathrm{CG}(\mathrm{T}-)$ & & & & & & $\underline{1.00}$ \\
\hline
\end{tabular}

The analyses were made through the Euclidean distance applied to the normalized matrices of the metabolic (a), biometric (b), and chemical (c) attributes. These attributes were modeled in a double factorial scheme $\left(\mathrm{Y} \sim \operatorname{biochar}{ }^{*}\right.$ T. aureoviride) and submitted to permutational multivariate analysis of variance through the Adonis pseudo-F significance test, where segregations $\left(r^{2}\right)$ with $\rho \leq .05$ are significant: Metabolic (a) biochar $\left(r^{2}=.64, \rho \leq .001\right), T$. aureoviride $\left(r^{2}=.008, \rho \leq .785\right)$, and biochar $\mathrm{x}$ T. aureoviride $\left(r^{2}=.10 ; \rho \leq .021\right)$; Biometrics (b) biochar $\left(r^{2}=.57, \rho \leq\right.$ $.001), T$. aureoviride $\left(r^{2}=.09, \rho \leq .003\right)$, and biochar $\mathrm{x}$ T. aureoviride $\left(r^{2}=.11 ; \rho \leq .006\right) ;\left(r^{2}=.022, \rho \leq .665\right)$, and biochar $\mathrm{x}$ T. aureoviride $\left(r^{2}=.022, \rho \leq .665\right)$, and T. aureoviride $\left(r^{2}=.025, \rho \leq .231\right)$

Analyses of the correlations between the scores of the two major components of nMDS showed that the first relevant ordering (nMDS1) had significant positive correlations with the chemical attributes $\mathrm{pH}, \mathrm{P}, \mathrm{K}^{+}$, $\mathrm{Ca}^{2+}$, and $\mathrm{Mg}^{+2}$ and had negative correlations with $\mathrm{Al}^{3+}$ (Table 5). The second ordering (nMDS2) showed strong positive correlations with all biometric attributes, and were significant for LEN, SFB, SDB, and RDB (Table 5). Thus, the dispersions of the metabolic pattern of the microbial communities are primarily explained by the chemical attributes of the soil and then by the responses of the plants in terms of development because of the chemical changes in the soil. 
Table 5. Correlation coefficients $\left(r^{2}\right)$ between the explanatory variables and the first two axes of nonparametric multidimensional scaling (nMDS: non-metric multidimensional scaling)

\begin{tabular}{|c|c|c|c|c|c|}
\hline & nMDS1 & nMDS2 & $r^{2}(*)$ & $\mathrm{P}_{\mathrm{r}}\left(>\mathrm{r}^{+}\right)$ & \\
\hline \multicolumn{6}{|c|}{ a. Metabolic attribute } \\
\hline Ure & 0.999 & -0.051 & 0.80 & 0.001 & *** \\
\hline Beta & -0.967 & 0.255 & 0.81 & 0.001 & *** \\
\hline P.Alk & -0.472 & -0.882 & 0.63 & 0.001 & *** \\
\hline P.Aci & -0.586 & 0.810 & 0.50 & 0.002 & ** \\
\hline TOC & -0.374 & 0.928 & 0.53 & 0.001 & *** \\
\hline MBC & 0.678 & 0.735 & 0.56 & 0.001 & *** \\
\hline$q \mathrm{CO} 2$ & -0.209 & -0.978 & 0.85 & 0.001 & $* * *$ \\
\hline \multicolumn{6}{|c|}{ b. Biometric attribute } \\
\hline LEN & 0.153 & 0.988 & 0.33 & 0.026 & $*$ \\
\hline DIA & 0.218 & 0.976 & 0.17 & 0.174 & ns \\
\hline SFM & 0.115 & 0.993 & 0.45 & 0.002 & ** \\
\hline RFM & -0.591 & 0.807 & 0.07 & 0.538 & ns \\
\hline SDM & 0.130 & 0.992 & 0.29 & 0.033 & $*$ \\
\hline RDM & 0.133 & 0.991 & 0.39 & 0.008 & ** \\
\hline \multicolumn{6}{|c|}{ c. Chemical attribute } \\
\hline $\mathrm{pH}$ & 0.995 & -0.103 & 0.72 & 0.001 & *** \\
\hline $\mathrm{Na}^{+}$ & -0.267 & -0.964 & 0.02 & 0.865 & ns \\
\hline $\mathrm{K}^{+}$ & 1.000 & -0.025 & 0.59 & 0.002 & ** \\
\hline $\mathrm{P}$ & 0.848 & 0.530 & 0.49 & 0.002 & ** \\
\hline $\mathrm{H}+\mathrm{Al}$ & -0.999 & -0.055 & 0.65 & 0.001 & $* * *$ \\
\hline $\mathrm{Ca}^{2+}$ & 0.911 & 0.412 & 0.36 & 0.024 & $*$ \\
\hline $\mathrm{Mg}^{2+}$ & 0.819 & 0.574 & 0.56 & 0.003 & ** \\
\hline $\mathrm{Al}^{3+}$ & 0.304 & -0.953 & 0.13 & 0.300 & ns \\
\hline
\end{tabular}

${ }^{*}$ Adjustment statistics by squared correlation coefficient $\left(r^{2}\right)$. + Significance intervals $(\operatorname{Pr}): 0{ }^{* * *} 0.001{ }^{* *} 0.01{ }^{*} 0.05 \mathrm{~ns}$ 1.Ure= soil Urease; $B$ eta $=\beta$-glycosidase; $\mathrm{P} . \mathrm{alk}=$ alkaline phosphatase; $\mathrm{P}$. aci $=$ acid phosphatase activities; $\mathrm{TOC}=$ total organic carbon; $\mathrm{MBC}=$ microbial biomass carbon; $\mathrm{qCO} 2=$ soil metabolic quotient; $\mathrm{LEN}=$ plant length; $\mathrm{DIA}=$ diameter; $S F M=$ shoot fresh mass; $R F M=$ root fresh mass; $S D M=$ shoot dry mass; RDM= root dry mass

The Mantel complementary test confirmed significant positive correlations between the metabolic and biometric attributes $(r=0.32, \rho=0.003)$, metabolic and chemical attributes $(r=0.53, \rho=0.001)$, and chemical and biometric attributes $(r=0.34, \rho=0.009)$. By internally analysing these interactions through the matrices with the Pearson coefficient $\left(R_{p}\right)$, it was possible to evaluate the degree of dependence between the variables associated with the pairs (Figure 2). 

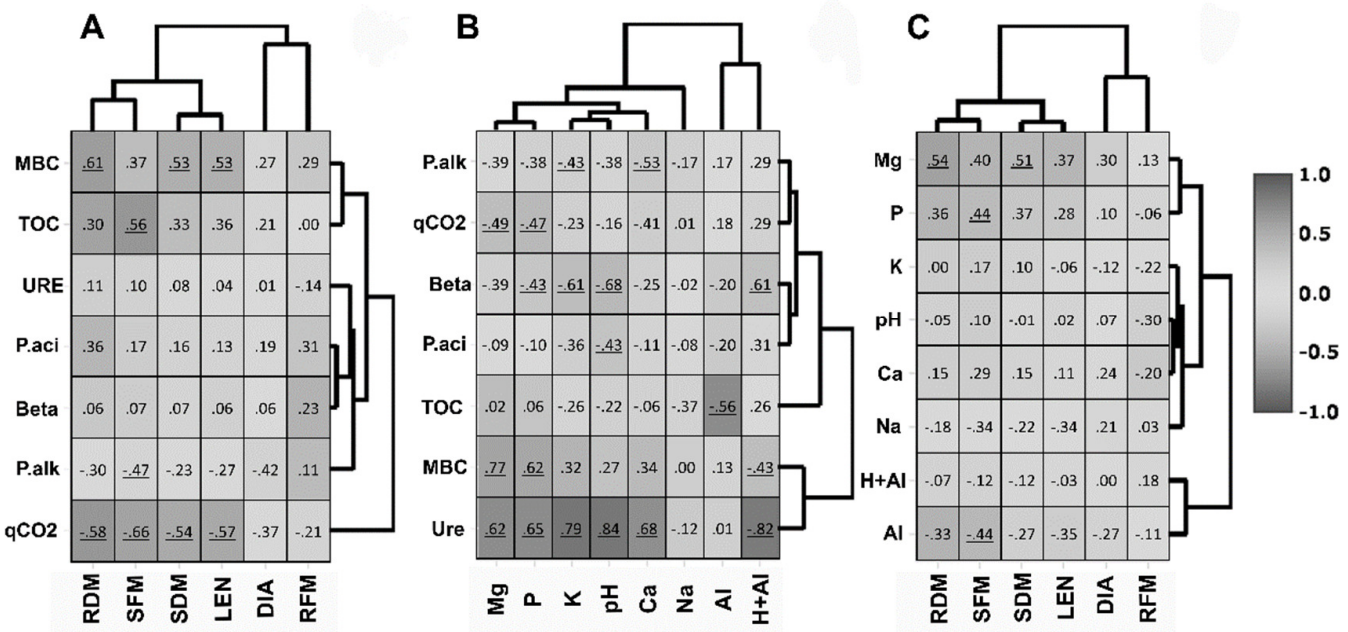

Figure 2. Correlations between enzymatic activities, soil chemical attributes, and biometric data of watermelon plants grown on soils under different biochar treatments with and without Trichoderma aureoviride. The heatmap and Pearson correlation coefficients $(R p)$ station were used to associate the paired samples. The underlined correlations are significant $(\rho \leq .05)$. In general, the Mantel test revealed significant positive correlations between soil metabolic attributes and plant biometric $(\mathbf{A}, r=0.32, \rho=$ $0.003)$, soil metabolic, and chemical attributes $(\mathbf{B}, r=.53, \rho=0.001)$, and chemical and biometric attributes $(\mathbf{C}, r=0.34, \rho=0.009)$

Urease (Ure), $\beta$-glycosidase (Beta), alkaline phosphatase (P.Alk), acid phosphatase (P.Aci), total organic carbon (TOC), microbial biomass carbon (MBC), soil metabolic quotient (qCO2); root dry matter (RDM) and root fresh matter (RFM), shoot dry mass (SDM), and shoot fresh matter (SFM), length (LEN) and diameter (DIA) of watermelon branches

Regarding the interaction between metabolic and biometric attributes, soil MBC showed positive correlations with RDB, SDB, and LEN of the watermelon plants (Figure 2A). The increase in the TOC in the soil was accompanied by an increase in SFB and P. alk correlated with SDB. Metabolic and chemical attribute interactions highlighted the significant and positive correlations of soil Ure activity with $\mathrm{pH}, \mathrm{Mg}^{2+}, \mathrm{P}, \mathrm{K}^{+}$, and $\mathrm{Ca}^{2+}$ content and the negative correlation with $\mathrm{H}+\mathrm{Al}^{3+}$. $\mathrm{MBC}$ also showed positive correlations with $\mathrm{Mg}^{2+}$ and $\mathrm{P}$ (Figure 2B). Regarding the interaction between chemical and biometric attributes (Figure 2C), the significant and positive correlations of $\mathrm{Mg}^{2+}$ with $R D B$ and $S D B$ and $\mathrm{P}$ with $\mathrm{SDB}$ were highlighted. The only remaining significant correlation was between $\mathrm{Al}^{3+}$ and $\mathrm{SDB}$, demonstrating the negative effect of exchangeable $\mathrm{Al}^{3+}$ on the labile $\mathrm{P}$ and on the growth of the aerial part of the plants.

All the metabolic variables significantly responded to the isolated effect of the biochar source, the only exception begin P. Alk. The isolated effect of T. aureoviride inoculation was significant only for Beta and $q \mathrm{CO}_{2}$ (metabolic attributes). However, the effect of the interaction of biochar $\times \mathrm{T}$ was significant for Ure, Beta, TOC, and MBC, showing the potential of this combination in these processes.

\section{Discussion}

The different sources of organic matter used to produce the biochar generated products with different properties, mainly in the chemical attributes of the soils that received the biochar (Figure 1). Several studies showed that biochar sources as manure, coffee bark, and bean hulls that are rich in nutrients, sawdust, pine bark, and sugar cane bagasse can provide diverse agronomic and environmental benefits such as a high content of $\mathrm{KHCO}_{3}$ and $\mathrm{CaCO}_{3}$ associated with the ash of these materials, increasing the $\mathrm{pH}$ and $\mathrm{Ca}^{2+}$ content in the soils. The soil attributes can vary by source as shown in previous studies (Domingues et al., 2017; Lee et al., 
2019; Song et al., 2019). Here, we used three different sources, two from coffee and one from bean residues, that also showed differences in these and other soil chemical attributes, confirming that biochar production source influences soil fertility. The sandy soil cultivating watermelon that received biochar CG showed fewer macronutrients because it is a thermally pre-processed source; part of its nutrients is removed after infusion into water. However, its participation in the activation of the enzymes $\beta$-glucosidase and acid phosphatase was significantly higher than that found in $\mathrm{CH}$. B-glucosidase facilitates the decomposition of low molecular weight carbohydrates, producing glucose, which is fundamental in the terrestrial cycle of $\mathrm{C}$ to supply the energy necessary for the proliferation of soil microorganisms (Eivazi and Tabatabai, 1990). Therefore, CG was a significant stimulant of $\beta$-glucosidase producing microbial communities. Notably, the increase in the activity of this enzyme accompanied the TOC (substrate) and the activity of acid phosphatase, according to the positive and significant correlations of these variables with the second ordering of nMDS (Figure 1, Table 5).

The similarity between the expressions of $\beta$-glucosidase and acid phosphatase in soils that received CG can be explained by the fact that these enzymes mitigate the discharge of bioavailable nutrients of organic carbon and phosphorus in the soil (Sinsabaugh et al., 2014), which were stimulated by the addition of organic materials as shown in two European long-term field experiments (Böhme et al., 2005). Positive and significant correlations between phosphatases and organic carbon are already well known from a previous study (Kumari et al., 2017). However, explanations for these mechanisms are not well justified.

In view of these positions and different enzymatic expressions, the present study proposed the hypothesis that the biochar of CG selects groups of distinct microorganisms that are favoured by biochars with more nutrients available - CG and BH. The higher aggregate expression of $\beta$-glucosidase and acid phosphatase in soils with CG corroborates this assertion, as these biochars led to a higher metabolism of organic materials by microorganisms in search of energy. In addition to the nature of the carbon source from the coffee biochars, the optimal pH range provided by these sources may explain the higher enzymatic activities. Acosta-Martínez and Tabatabai (2000) studied enzymatic activity in soils under different doses of limestone in Iowa (USA) and demonstrated that the activity of acid phosphatase was significantly and negatively correlated to soil $\mathrm{pH}$, with optimal performance at $\mathrm{pH}$ 6.5. This result corroborates that of the present study (Figure 2B), where soils with $\mathrm{CG}$ and $\mathrm{BH}$ showed a relative increase in acid phosphatase activity, contrasting with the $\mathrm{CH}$ biochar, which greatly increased the soil $\mathrm{pH}$ (Tables 2,3 ).

Organic waste accounts for most of the monoester phosphates in the soil, which is among the main organic sources of P (Turner, 2008). Thus, in acidic soils with low levels of nutrients and inorganic P, microorganisms are more dependent on the $\mathrm{P}$ forms associated with organic materials (Gatiboni et al., 2008). However, these metabolized compounds have a high affinity for soil colloids, where most of the microbiota cannot access them (Rheinheimer et al., 2001). In this aspect, biochar is once again advantageous because it can adsorb the soil nutrients on its surface, keeping them bioavailable for incorporation by microbial biomass or plants during phenolic stages of higher energy demand (Elzobair et al., 2016; Yang et al., 2017). In addition, the fungi Trichoderma spp. can also assist in plant nutrition by promoting the solubilization of some minerals, producing phytohormones, and increasing the efficiency of water use, defence, health, and plant development (Shoresh et al., 2010; Khan and Mohiddin, 2018).

In this context, $\mathrm{MBC}$ showed a relationship with total organic $\mathrm{C}$ and with acid phosphatase through approximations between both in the heatmaps (Figure 2A, 2B) and its strong positive and significant correlations with the second nMDS axis (Table 5). This relationship was discussed in Zhu et al. (2017), in which the addition of corn straw biochar under low pyrolysis $\left(450^{\circ} \mathrm{C}\right)$ in a dryland corn field in Northwest China increased the microbial biomass and the activity of phosphatases. Anders et al. (2013) showed that these increases were primarily attributed to the increase in $\mathrm{C}$ and the nutrients provided by biochar in the soil or by root activity. The present study also showed a greater approximation of RFB gain with TOC, in addition to acid phosphatase (Figure 1). This corroborates the work by Amendola et al. (2017), who verified the increase 
in organic carbon and biomass of fine roots of grapevine plants immediately after the application of only $10 \mathrm{t}$ ha $^{-1}$ of biochar.

Urease was the enzyme that most directly correlated with the soil chemical attributes (Figure 2B), which is similar to the result of Kandeler et al. (2006) in the 0-10 cm layer of a pasture soil in a semiarid region of northern Colorado (EUA, 25 a $60 \mathrm{NH}^{4+}-\mathrm{Ng}^{-1} 2 \mathrm{~h}^{-1}$ ). Urease is a metalloenzyme (EC 3.5.1.5) that performs the hydrolysis of urea, releasing $\mathrm{CO}_{2}$ and $\mathrm{NH}_{3}$ with increased activity to $\mathrm{pH} 10$ (Kandeler and Gerber, 1988). This explains their higher activity in soils with $\mathrm{CH}$ and $\mathrm{BH}$, sources that increased the soil $\mathrm{pH}$, tending to the optimal level of performance ( $\mathrm{pH} 10)$. This phenomenon is primarily attributed to of $\mathrm{Ca}^{2+}$ and $\mathrm{K}^{+}$carbonates, abundant in $\mathrm{CH}$ and $\mathrm{BH}$ biochar, which are also rich in $\mathrm{P}$ and $\mathrm{Mg}^{2+}$, such that the $\mathrm{pH}$ tends to increase along with the content of these nutrients in the soil, as its potential acidity decreases $\left(\mathrm{H}^{+}+\mathrm{Al}^{3+}\right.$, Figure $\left.2 \mathrm{~B}\right)$.

Notably, there are high positive and significant correlations of labile $\mathrm{P}$ and $\mathrm{Mg}^{2+}$ with $\mathrm{CBM}$ (Figure 2B). Regarding $\mathrm{P}$, this correlation is justified by its importance as a mediator in the energy transfer processes in the form of ATP and in the synthesis of nucleic acids, phospholipids, and molecular signals in the path of enzymatic phosphorylation. $\mathrm{Mg}^{2+}$ is also a cofactor and fundamental regulator of countless proteins with the presence of fundamental $\mathrm{P}$ in its transport to the interior of the prokaryotic cells. This is explained by extracellular $\mathrm{Mg}^{2+}$ with ATP as cofactors of $\mathrm{Mg}^{2+}$ hydrolase, importing ATPase (EC 3.6.3.2), the enzyme responsible for the release of phosphate and $\mathrm{M}^{2+}$ inside cells (Tao et al., 1995). In addition, in the present study, these nutrients were the only ones that significantly affected the dry mass gain of the shoot and roots (in the case of $\mathrm{Mg}$ ) and the fresh mass of the aerial part in the case of $\mathrm{P}$ (Figure 2C). In summary, the mechanisms of these interactions represent some of the several that reflect the importance of $\mathrm{PO}_{4}{ }^{3-}$ and $\mathrm{Mg}^{2+}$ availability for the development of watermelon plants and associated microbial communities.

In view of the variability between the responses to the different biochar sources on the chemical and enzymatic attributes of the soils, the choice of the best source is dependent on the purpose of its use. Although the $\mathrm{CH}$ and $\mathrm{BH}$ biochars provide more labile $\mathrm{P}$ and bases to the soil, increasing the $\mathrm{pH}$, the $\mathrm{CG}$ biochar is more relevant for the activation of acid phosphatase and $\beta$-glucosidase and an increase in soil organic carbon. In addition, all sources presented different relevance when considering inoculation with $T$. aureoviride (Figure 1), primarily on the development of plants (Table 1).

In general, the most significant contributions of $T$. aureoviride inoculation were the following (Table 1, 2, 3): I - increased fresh root mass, regardless of biochar; II - increased fresh and dry mass of the aerial part, in treatments with CG and BH; III - increased length of the main branches in treatments with CG; IV - increased branch diameter in treatments with CG and $\mathrm{BH}$; and $\mathrm{V}$ - increased root dry biomass in treatments with $\mathrm{CG}$ and primarily with $\mathrm{BH}$.

Similarly, Jalali et al. (2017) demonstrated the potential to promote Arabidopsis thaliana growth because of increased tolerance to salinity stress after inoculation with several species of Trichoderma spp., protecting plants against oxidative damage. Kiriga et al. (2018) also demonstrated that Trichoderma spp. can endophytically colonize the pineapple plant roots, protecting the culture against infestations of Meloidogyne javanica and fungi in the soil and increasing root mass and plant development. In general, there are numerous studies mentioning other benefits provided by several species of Trichoderma spp., such as increased root uptake (Oskiera et al., 2017), seed germination (Mendoza-Mendoza et al., 2018), and soil metabolic activity (Elzobair et al., 2016), among others. These references corroborate the significant increase in $\beta$-glucosidase activity as a function of $T$. aureoviride inoculation, independent of the biochar used, with greater relevance for CG (Table 3).

Considering only the chemical contributions, the greatest change was observed in soils with $T$. aureoviride inoculated with $\mathrm{BH}$, where there was a significant increase in the levels of labile $\mathrm{P}\left(\mathrm{Mehlich}^{-1}\right)$ and $\mathrm{Ca}^{2+}$ (Table 2). Corroborating this result, Saravanakumar et al. (2013) demonstrated that all ten species of Trichoderma spp., isolated from the rhizosphere Avicennia marina, a native species of mangroves, solubilized tricalcium phosphate $\left(\mathrm{Ca}_{3}\left(\mathrm{PO}_{4}\right)_{2}\right)$. This insoluble source of $\mathrm{P}$ induces the synthesis of the extracellular enzyme 
phytase by the isolates. The same study also showed that the re-inoculation of these isolates increased the biomass of $A$. marina cultivated in poor soil (in vitro) without phosphate supplementation by $19 \%$. Thus, this reference explains the simultaneous increases in exchangeable $\mathrm{Ca}$ and $\mathrm{P}$ content in soils with $T$. aureoviride and $\mathrm{BH}$, in addition to the enormous enzymatic versatility and potential of vegetal promotion of this species.

These changes in the means of the variables analyzed in response to inoculation with $T$. aureoviride are because of the physicochemical specificity of each material used as they affect soil aggregation (Amendola et al., 2017) and microbial community structure (Zhang et al., 2018).

\section{Conclusions}

This study showed a new approach of biochar as a route of $T$. aureoviride inoculation. Watermelon plants cultivated in soil with coffee ground biochar and inoculated with $T$. aureoviride have increased the plant length and shoot dry biomass by $129 \%$ and $192 \%$, respectively, compared to the control. The use of $T$. aureoviride via inoculation using different biochar sources showed sufficient characteristics for the development of a biological substrate with a high potential for the development of watermelon plants and improvement in the soil quality. This is even more relevant when considering the low production costs of these substrates compared to that of chemical fertilizers.

\section{Acknowledgements}

We thank fellowships and grants from CNPq (306401/2015-0 465764/2014-2 CNPq-441305/20172), CAPES (88887.736369/2017-00), FACEPE (APQ-0223-5.01/15; APQ-0419-5.01/15; APQ-04315.01/17; APQ-0498-3.07/17) and Micoteca URM collection of the Mycology Department of the Biological Sciences Center of the Federal University of Pernambuco for provided us the Trichoderma aureoviride URM 5158 isolate.

\section{Conflict of Interests}

The authors declare that there are no conflicts of interest related to this article.

\section{References}

Acosta-Martínez V, Tabatabai MA (2000). Enzyme activities in a limed agricultural soil. Biology and Fertility of Soils 31:85-91. https://doi.org/10.1007/s003740050628

Amendola C, Montagnoli A, Terzaghi M, Trupiano D, Oliva F, Baronti S, Scippa GS (2017). Short-term effects of biochar on grapevine fine root dynamics and arbuscular mycorrhizae production. Agriculture, Ecosystems and Environment 239:236-245. https://doi.org/10.1016/j.agee.2017.01.025

Anders E, Watzinger A, Remt F, Kitzler B, Wimmer B, Zehetner F (2013). Biochar affects the structure rather than the total biomass of microbial communities in temperate soils. Agricultural and Food Science 22:404-423. https://doi.org/10.23986/afsci.8095

Anderson TH, Domsch KH (1985). Determination of eco-physiological maintenance carbon requirements of soil microorganisms in a dormant state. Biology and Fertility of Soils 1(2):81-89. https://doi.org/10.1007/BF00255134 
Bartlett RJ, Ross DS (1988). Colorimetric determination of oxidizable carbon in acid soil solutions. Soil Science Society of America Journal 53:191-192. https://doi.org/10.2136/sssaj1988.03615995005200040055x

Böhme L, Langer U, Böhme F (2005). Microbial biomass, enzyme activities and microbial community structure in two European long-term field experiments. Agriculture, Ecosystems and Environment 109:141-152. https://doi.org/10.1016/j.agee.2005.01.017

Domingues RR, Trugilho PF, Silva CA (2017). Properties of biochar derived from wood and high-nutrient biomasses with the aim of agronomic and environmental benefits. Plos One 12 (5):e0176884. https://doi.org/10.1371/journal.pone.0176884

Eivazi F, Tabatabai MA (1990). Factors affecting glucosidase and galactosidase activities in soils. Soil Biology and Biochemistry 22:891-897. https://doi.org/10.1016/0038-0717(90)90126

Eivazi F, Tabatabai M A (1977). Phosphatases in soils. Soil Biology and Biochemistry 9:167-172. http://dx.doi.org/10.1016/0038-0717(77)90070-0

Eivazi F, Tabatabai MA (1988). Glucosidases and galactosidases in soils. Soil Biology and Biochemistry 20(5):601-606. https://doi.org/10.1016/0038-0717(88)90141-1

Elzobair KA, Stromberger ME, Ippolito JA, Lentz RD (2016). Contrasting effects of biochar versus manure on soil microbial communities and enzyme activities in an Aridisol. Chemosphere 142:145-152. https://doi.org/10.1016/j.chemosphere.2015.06.044

Gatiboni LC, Rheinheimer DS, Brunetto GB (2008). Soil microbial biomass phosphorus and activity of acid phosphatases during decline of soil available phosphorus. Pesquisa Agropecuária Brasileira 43(8):1085-1091.

Jalali F, Zafari D, Salari H (2017). Volatile organic compounds of some Trichoderma spp. increase growth and induce salt tolerance in Arabidopsis thaliana. Fungal Ecology 29:67-75.

Khan MR, Mohiddin FA (2018). Trichoderma: its multifarious utility in crop improvement. In: Crop Improvement Through Microbial Biotechnology. Elsevier pp 263-291.

Kandeler E, Gerber H (1988). Short-term assay of soil urease activity using colorimetric determination of ammonium. Biology and Fertility of Soils 6:68-72. http://dx.doi.org/10.1007/BF00257924

Kandeler, E, Mosier A, Morgan J (2006). Response of soil microbial biomass and enzyme activities to transient elevation of carbon dioxide in a semi-arid grassland. Soil Biology and Biochemistry 38:2448-2460. https://doi.org/10.1016/j.soilbio.2006.02.021

Kiriga AW, Haukeland S, Kariuki GM, Coyne DL, Beek NV (2018). Effect of Trichoderma spp. and Purpureocillium lilacinum on Meloidogyne javanica in commercial pineapple production in Kenya. Biological Control 119:27-32.

Kumari A, Rao PC, Padmaja G, Madhavi M (2017). Effect of physico-chemical properties on soil enzyme acid phosphatase activity of some soils in vegetable growing soils of Ranga Reddy District of Telangana State, India. International Journal of Current Microbiology and Applied 6(10):3496-3503. https://doi.org/10.20546/ijcmas.2017.610.412

Lee ME, Park JH, Chung JW (2019). Comparison of the lead and copper adsorption capacities of plant source materials and their biochars. Journal of Environmental Management 236:118-124. https://doi.org/10.1016/j.jenvman.2019.01.100

Lima JRS, Silva WM, Medeiros EV, Duda GP, Corrêa MM, Martins Filho AP, Hammecker C (2018). Effect of biochar on physicochemical properties of a sandy soil and maize growth in a greenhouse experiment. Geoderma 319:14-23. https://doi.org/10.1016/j.geoderma.2017.12.033

Mendonca ES, Matos ES (2005). Matéria orgânica do solo: Métodos de análises. Universidade Federal de Viçosa (UFV), Viçosa, Brasil pp 86-92.

Mendoza-Mendoza A, Zaid R, Lawry R, Hermosa R, Monte E, Horwitz BA, Mukherjee PK (2018). Molecular dialogues between Trichoderma and roots: Role of the fungal secretome. Fungal Biology Reviews 32:62-85.

Oskiera M, Szczech M, Stępowska A, Smolińska U, Bartoszewski G (2017) Monitoring of Trichoderma species in agricultural soil in response to application of biopreparations. Biological Control 113:65-72. https://doi.org/10.1016/j.biocontrol.2017.07.005

Patel A, Khare P, Patra DD (2017). Biochar mitigates salinity stress in plants. In: Shukla V, Kumar S, Kumar N (Eds). Plant adaptation strategies in changing environment. Springer, Singapore, pp 153-182. 
Poduria A, Rateria DL, Sahab SK, Sahac S, Daugherty A (2013). Citrullus lanatus 'sentinel' (watermelon) extract reduces atherosclerosis in LDL receptor-deficient mice. The Journal of nutritional biochemistry 24:882-886. https://doi.org/10.1016/j.jnutbio.2012.05.011

Raij B, Van Andrade JC, Cantarella H, Quaggio JA (2001). Análise química para avaliação da fertilidade de solos tropicais. Campinas: Instituto Agronômico pp 284.

Rheinheimer DS, Anghinoni I (2001). Distribution of inorganic phosphorus fraction in soil management systems. Pesquisa Agropecuária Brasileira 36:151-160.

Saravanakumar K, Arasu VS, Kathiresan K (2013). Effect of Trichoderma on soil phosphate solubilization and growth improvement of Avicennia marina. Aquatic Botany 104:101-105. https://doi.org/10.1016/j.aquabot.2012.09.001

Saxena, J, Rana G, Pandey M (2013). Impact of addition of biochar along with Bacillus sp. on growth and yield of French beans. Scientia Horticulturae 162:351-356. https://doi.org/10.1016/j.scienta.2013.08.002

Shoresh M, Harman GE, Mastouri F (2010). Induced systemic resistance and plant responses to fungal biocontrol agents. Annual Review of Phytopathology 48:21-43. https://doi.org/10.1146/annurev-phyto-073009-114450

Silva FC (2009). Manual de análises químicas de solos, plantas e fertilizantes. 2.ed. Brasília, DF: Embrapa Informação Tecnológica; Rio de Janeiro: Embrapa Solos, pp 627.

Silva JAT, Medeiros EV, Silva JM, Tenório DDA, Moreira KA, Nascimento TCEDS, Souza-Motta C (2016). Trichoderma aureoviride URM 5158 and Trichoderma hamatum URM 6656 are biocontrol agents that act against cassava root rot through different mechanisms. Journal of Phytopathology 164:1003-1011. https://doi.org/10.1111/jph.12521

Sinsabaugh RL, Belnap J, Findlay SG, Shah JJF, Hill BH, Kuehn KA (2014). Extracellular enzyme kinetics scale with resource availability. Biogeochemistry 121:287-304. https://doi.org/10.1007/s10533-014-0030-y

Song B, Chen M, Zhao L, Qiu H, Cao X (2019). Physicochemical property and colloidal stability of micron-and nano-particle biochar derived from a variety of feedstock sources. Science of the Total Environment https://doi.org/10.1016/j.scitotenv.2019.01.193

Tao T, Snavely MD, Farr SG, Maguire ME (1995). Magnesium transport in Salmonella typhimurium: mgtA encodes a P-type ATPase and is regulated by $\mathrm{Mg} 2+$ in a manner similar to that of the mgtB P-type ATPase. Journal of Bacteriology 177(10):2654-62. https://doi.org/10.1128/jb.177.10.2654-2662.1995

Tate KR, Ross DJ, Feltham CW (1988). A direct extraction method to estimate soil microbial C: effects of experimental variables and some different calibration procedures. Soil Biology and Biochemistry 20:329-335. https://doi.org/10.1016/0038$0717(88) 90013-2$

Turner BL (2008) Resource partitioning for soil phosphorus: a hypothesis. Journal of Ecology 96:698-702. https://doi.org/10.1111/j.1365-2745.2008.01384.x

Yang X, Meng J, Lan Y, Chen W, Yang T, Yuan J, Han J (2017). Effects of maize stover and its biochar on soil CO2 emissions and labile organic carbon fractions in Northeast China. Agriculture, Ecosystems and Environment 240:24-31. https://doi.org/10.1007/s11356-017-8500-0

Yeomans JC, Bremner JM (1988). A rapid and precise method for routine determination of organic carbon in soil. Communications in Soil Science and Plant Analysis 19:1467-1476. https://doi.org/10.1080/00103628809368027

Zhang P, Sun H, Min L, Ren C (2018). Biochars change the sorption and degradation of thiacloprid in soil: Insights into chemical and biological mechanisms. Environmental Pollution 236:158-167. https://doi.org/10.1016/j.envpol.2018.01.030

Zhu LX, Xiao Q, Cheng HY, Shi BJ, Shen YF, Li SQ (2017). Seasonal dynamics of soil microbial activity after biochar addition in a dryland maize field in North-Western China. Ecological Engineering 104:141-149. https://doi.org/10.1016/j.ecoleng.2017.04.026 
The journal offers free, immediate, and unrestricted access to peer-reviewed research and scholarly work. Users are allowed to read, download, copy, distribute, print, search, or link to the full texts of the articles, or use them for any other lawful purpose, without asking prior permission from the publisher or the author.

(c) (i)

License - Articles published in Notulae Botanicae Horti Agrobotanici Cluj-Napoca are Open-Access, distributed under the terms and conditions of the Creative Commons Attribution (CC BY 4.0) License. (c) Articles by the authors; UASVM, Cluj-Napoca, Romania. The journal allows the author(s) to hold the copyright/to retain publishing rights without restriction. 